\title{
The Pithotomy Club: R.I.P.
}

\author{
William H. Jarrett II, MD
}

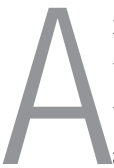

faculty member at Johns Hopkins once remarked that there are three great institutions in the Western World: the Roman Catholic Church, the Holy Roman Empire, and the Pithotomy Club. I am sure that you recognize the first two items in this list, but what in the world is the Pithotomy Club? Alas, this wonderful institution is no more, but it played a vital and significant role in the social life of The Johns Hopkins Medical School during most of the first century of that institution's existence.

The Pithotomy Club was the creation of the very first class to graduate from The Johns Hopkins Medical School, the class of 1897 . As their years of medical school were coming to an end, several members of that class felt the need to forge stronger bonds of collegiality amongst themselves and the medical school faculty. Eight of the students began to meet at each other's boarding houses on the weekend, where they would enjoy a keg of beer and some singing, accompanied by a piano and violin-playing classmates. They began to take their noon-day meals together at a nearby bar, a place also frequented by Osler, Welch, and some of the other faculty. Occasionally some faculty were invited to Saturday evening housewarming parties, and these experiences proved enjoyable to all concerned.

The Pithotomy Club evolved from such beginnings. The name of the club is Greek in origin and reflects the broad classical education of medical students in bygone days. The word pithos is Greek for keg, or barrel, and of course otomy means to cut into, or open. Hence, pithotomy means literally to open up a barrel, or, more colloquially, to tap a keg.

Lest the founders of the club be regarded as lightweight, fun-loving frat boys of dubious academic distinction, consider the subsequent careers of some of the founders:

- William G. McCallum, the student who coined the pithotomy name, succeeded William $\mathrm{H}$. Welch as chairman of pathology at Hopkins, wrote the standard textbook in pathology, widely used by several succeeding generations of students, and wrote a biography of another of his teachers, William S. Halsted.

- Eugene Opie became a distinguished experimental pathologist.

- Richard Strong became professor of tropical medicine at Harvard.

- Charles R. Bardeen became professor of anatomy at the University of Wisconsin.

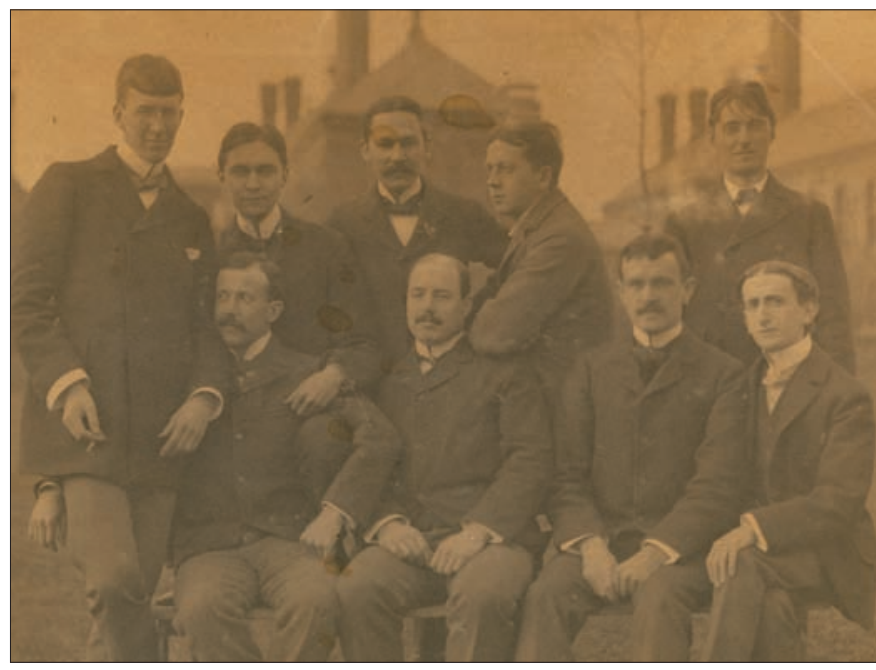

Figure 1. The founders of the Pithotomy Club. Reprinted with permission of the Alan Mason Chesney Medical Archives of The Johns Hopkins Medical Institutions

- Louis Hamberger and Thomas R. Brown became respected clinicians at Hopkins, and the latter served as a university trustee. He also discovered the relationship between eosinophilia and trichinosis.

So, although their names are not familiar to 21 st-century physicians, these were individuals of accomplishment and stature who were honored in their generation (Figure 1).

Through the years, the Pithotomy Club has produced countless professors, numerous department heads at Hopkins and elsewhere, several deans, and one Nobel prize winner, Dr. George Whipple. Nationally prominent physicians such as Wilder Penfield, W. Barry Wood, Wilburt C. Davison, and Charles Janeway were Pithotomists while studying medicine at Johns Hopkins.

In the beginning, membership was restricted to senior medical students, and high academic standing was a requirement for admission. Thus, early on, membership in the Pithotomy Club was considered an honor, and the club acquired a reputation as an elite organization. Since houseofficers at The

Presented in part at the annual meeting of the American Osler Society.

Corresponding author: William H. Jarrett II, MD, 200 Nacoochee Drive NW, Atlanta, Georgia 30305 (e-mail: LCWJ@aol.com). 
Johns Hopkins Hospital were appointed on the basis of class standing, many of these were Pithotomists as well.

The handwritten constitution of the club lays out the raison detre of the society: "The object of this Society is the promotion of vice among the virtuous, virtue among the vicious, and good fellowship among all." In addition, the club was "to facilitate the advancement of its members in the art and science of medicine by the promotion of social intercourse between the faculty and students of the Society." Although these documents were amended in subsequent years, the original intent guided the club for the 95 years of its existence.

After a decade or so, membership was extended to students in all four medical school classes. In 1908 a row house at 510 North Broadway, across the street from the hospital, was purchased and served as the club's home until 1954, when the original building was razed to make room for a medical office building. The club moved a couple of blocks north on Broadway, to \#731 (Figure 2), and remained in that location until 1983, when again the building found itself in the path of hospital expansion, and the club was forced to move once again, this time to a shabby, rundown, rat-infested clubhouse around the corner on Madison Street. Eventually, this building was given to Hopkins, and now a research building occupies that space as well.

Along with three other national medical fraternities at Hopkins, the Pithotomy Club functioned as a fraternity for its members. This filled a major need for the students, most of whom were unmarried and lived in boarding houses near the hospital. The major feature distinguishing Pithotomy from the others was the yearly Pithotomy show, as discussed later in this article.

The club owned a piano, a pool table, comfortable chairs, a sofa, and a TV for diversion. The walls and stairwell were lined with autographed photographs of prominent Hopkins faculty, both past and present, as well as class photos of previous members. There was an elegant fireplace, with a mantle donated by Edward L. Trudeau, the famed tuberculosis researcher, inscribed "In memory of an evening spent with the boys, ELT 1912."

There were living accommodations for three students, and the club employed a cook who prepared three hot meals a day. The eating arrangements made it possible for students to know and make friends with members of the other three classes, and one could learn quite a lot about medicine by listening attentively at meal times. Once or twice a month, faculty members

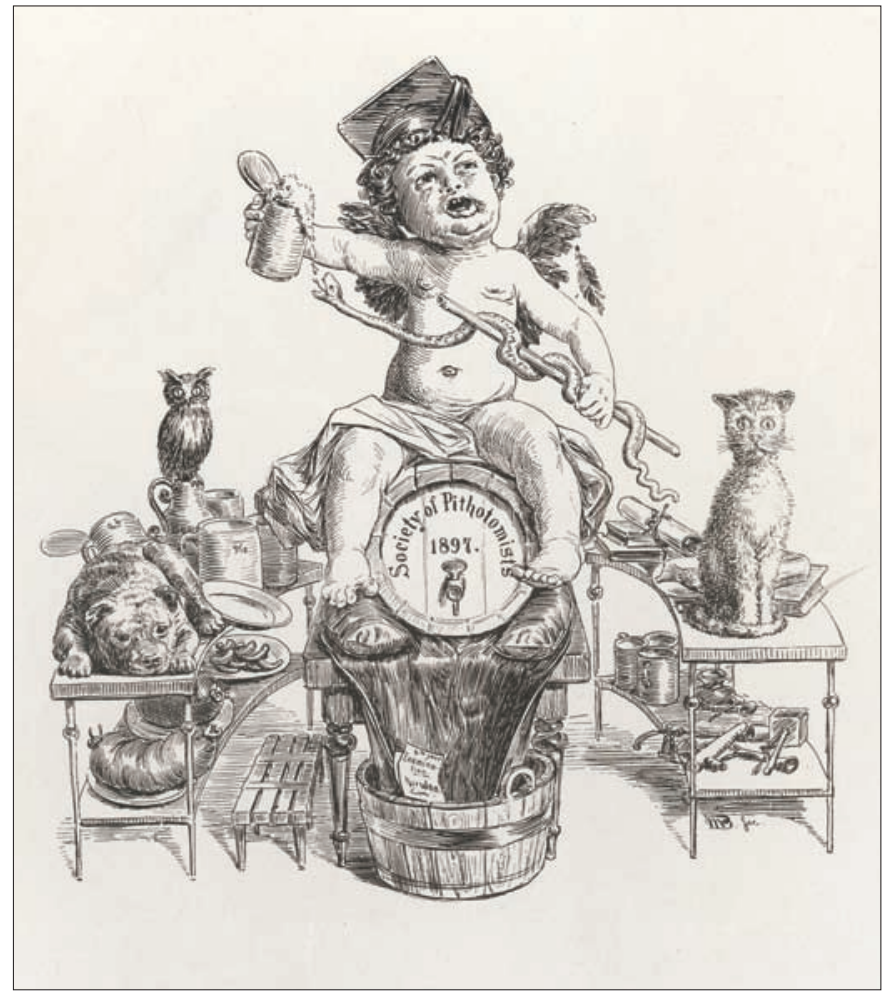

Figure 3. The emblem of the club, as designed by Max Broedel. Reprinted with permission of the Alan Mason Chesney Medical Archives of The Johns Hopkins Medical Institutions.

were invited for dinner and an informal conversation with the students, thus fulfilling the club's objective of fostering social exchange between faculty and students.

The club served other important social functions as well. In the early days, Pithotomy dances were held in the physiology building, and eligible young Baltimore ladies were invited. Chaperones to these dances included Mrs. Grace Revere Osler, Mrs. Hugh Young, and Mrs. J. M. T. Finney, all wives of prominent faculty members at Hopkins. There were weekend parties and dances, outings to Homewood or Annapolis for a lacrosse game or a crew race, and excursions to nearby women's colleges such as Goucher and Hood College.

Several emblems and insignia served to set the club apart and create a distinctive "brand." The first of these is a painting created for the club in 1897 by Max Broedel, the famous professor of art as applied to medicine at Johns Hopkins. Broedel gained renown for his beautifully accurate and detailed anatomic sketches, which illustrated medical articles by Halsted, Kelly, T. S. Cullen, and other Hopkins luminaries. For Pithotomy, he pictured a cherub seated astride a beer barrel, attired in a loin cloth and mortarboard, surrounded by various medical impedimenta, several animals, and properly discarded examination papers (Figure 3). This drawing became the club's official emblem and adorned its stationery and invitations. This symbolism was recreated in the singing of "3000 Years Ago," the traditional ending of the Pithotomy show.

A second talisman, still honored today by diehard Pithotomists, is the wearing of a special club tie on Wednesdays 
(Figure 4). The tie came into existence in the 1940s when a Pithotomy alumnus was traveling in England and became enchanted by the English regimental tie with its broad colorful stripes. He decided to create a special tie for the Pithotomy Club, using the Hopkins colors of blue and black and adding the traditional green of medicine. Once the pattern was decided upon, Brooks Brothers agreed to produce the tie exclusively for the club's use. Each new member received a tie at the time of his initiation. Later on a bow tie became available as well. This tradition preceded by several decades the wearing of an Osler tie on Fridays, a custom instituted by Victor McKusick during the 1970s when he was chairman of medicine.

There was even a Pithotomy flag, created by a sailmaker on the shores of Lake Geneva, in Switzerland. The flag is in the aforementioned black, blue, and green, with a large PC embossed on it. The flag was flown on Wednesdays and on show days. In 1979 a group of Pithotomists took the flag along on a sailing trip to the Bahamas and proudly flew it from the mast.

\section{THE PITHOTOMY CLUB IN LITERATURE}

The Pithotomy Club has enjoyed some exposure in literature and in the media, not all of which has been favorable. The club is mentioned in that charming novel about life in the early days at Hopkins, Miss Susie Slagle's. The author wrote, "Tho it is one of the most select medical clubs in America, the Pithotomy, like many another thing about Hopkins, was housed in the most mundane of buildings."

F. Scott Fitzgerald featured the Pithotomy Club in one of his short stories, "One Interne." He very accurately described a show and even quoted some verses of " 3000 Years Ago," describing it as a "witty, scurrilous, and interminable song which described the failings and eccentricities of the medical faculty." Another Baltimore scribe, H. L. Mencken, almost never missed a Pithotomy show, which was right down his alley (Figure 5). He thought the show represented a unique example of bawdy literary humor, rivaled only by that of British sailors.

In his magisterial biography of Osler, Harvey Cushing, who had arrived on the Hopkins scene in 1896, mentioned an early Pithotomy burlesque: "There had been festive occasions with song and refreshments in which students and teachers participated and in which the foibles of the teachers in particular were not spared in burlesque."

In 1948 a reporter from The Baltimore Sun attended a show and subsequently wrote an article about it. The article stated:

Sitting in one of the rows of chairs which replace the usual clubhouse furniture, you would have seen what makes the Pithotomy a name to be reckoned with in the Hopkins. Seated in the first row are some of the greatest names in contemporary

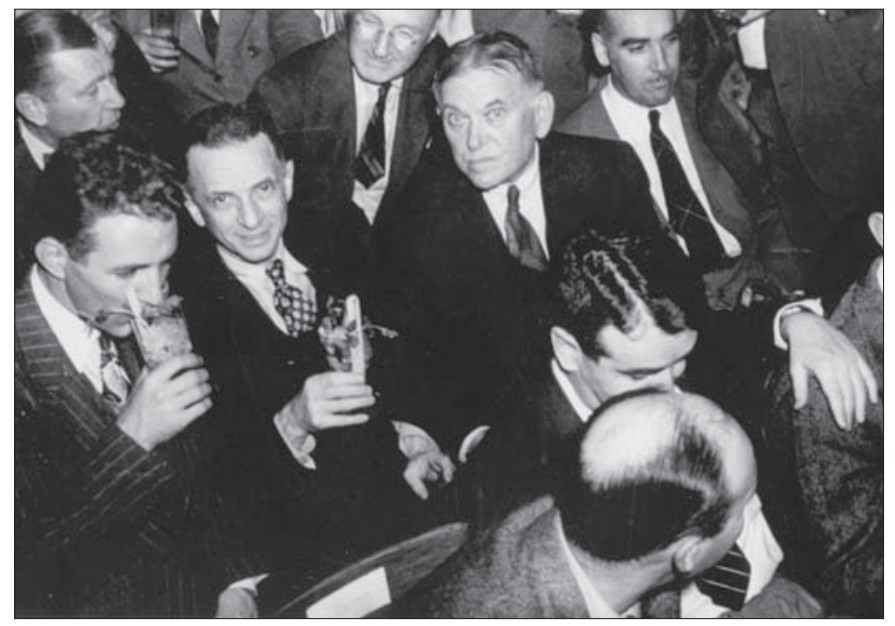

Figure 5. H. L. Mencken attending the 1948 Pithotomy shows. Mencken is on the right, facing the camera, sitting next to Dr. Arnold Rich and Dr. Bill Rienhoff Jr. Reprinted with permission of the Alan Mason Chesney Medical Archives of The Johns Hopkins Medical Institutions.

medicine. There are no women. It is considered a sign that a man has made his mark at the Hopkins when he is subjected to the withering scorn of the Pithotomists.

The paper also had a talented cartoonist, Yardley, who composed his whimsical "Medical Students at Play" to accompany the article. Reproductions of this cartoon adorned the walls of a hospital cafeteria for many years.

\section{THE PITHOTOMY SHOW}

Interestingly, an article has appeared in the peer-reviewed literature about the phenomenon of raucous medical student parodies of their professors. In an article entitled "Medicine's Moment of Misrule: The Medical Student Show," Hayter viewed these endeavors in a favorable light and pointed out that many other schools, in addition to Hopkins, participated in these traditional yearly hijinks. This list included Harvard and its second-year show, Michigan with its Smoker, the University of Toronto with its Daffydil, and a medical variety night at Queen's University in Kingston, Ontario. St. Bart's, in London, and schools in such varied cultures as Turkey, Israel, and China have produced similar events. The author quoted an observer of the Daffydil at Toronto: "It is undoubtedly the most important therapeutic agent ever produced at the University of Toronto's School of Medicine." Lest it escape your notice, insulin was discovered by University of Toronto researchers.

A quotation from a poem by Scotland's beloved Bobby Bums best describes the spirit in which the Pithotomy show was offered year after year:

O wod some power thi

giftie gie us, to see

oursels as others see us

Words cannot adequately describe a Pithotomy show; one truly has to experience it to know what it is all about. It is basically a burlesque of the junior and senior faculty, in which their foibles, failings, and unhappy character traits are laid bare 
for all to see. The format is that of a one-act musical play, with an elaborate plot loosely based on some actual recent event at Hopkins. As an example, one year the plot evolved over the visit of Prince Rainier of Monaco to the Johns Hopkins Hospital for a checkup prior to his marriage to Princess Grace, during which he had an uneventful hernia repair. All sorts of potential complications and contortions and distortions were then contrived by the fertile young minds of the medical students and adapted to the stage.

About a month prior to the show, which occurred in the late spring, third-and fourth-year students gathered in the evenings to brainstorm about a plot, plan dialogue, and compose bawdy lyrics to currently popular tunes. Their product was irreverent, obscene, funny, and occasionally elegant. One year the entire show was written in rhyming couplets. It was accompanied by a "program" whose very name prohibits mention in mixed company. The show is rarely vindictive or vicious, although on occasion it becomes payback time for a student who felt unjustly harassed by a particular faculty member.

The show extended over a three-night period. The Thursday evening performance was a dress rehearsal, to which other students and housestaff were invited. For many years women were totally excluded, but these standards were relaxed at the end, and a Wednesday night performance was added for women only. The content of the show, however, was not changed for feminine ears. The Friday night show was for senior housestaff and junior faculty, while the concluding Saturday evening performance was reserved for the deans, department heads, and senior faculty. Beer was the beverage of choice for the first few nights, while mint juleps were served on Saturday night.

Rather than spurning the Pithotomy show, the senior faculty, especially those who had been around for a while, looked forward to it with great gusto and enjoyed their "roasting" at the hands of their students. One prominent department chairman mentioned in his memoirs the name of the student who had done an excellent portrayal of him in the show; that individual eventually became the dean at Yale. Another replied to a Pithotomy invitation as follows: "RSVP? No one declines an invitation to a Pithotomy!" Actually, it was more unsettling to be ignored by the Pithotomists than to be ridiculed. Many an up-and-coming faculty member was pleasantly surprised to find himself a target of the show, a sure sign that he had "arrived."

Indeed, the Pithotomy Club and its show attained an aura, a mystique that was reflected in numerous whimsical letters to the club regarding the show. One physician telegraphed his apologies for his delayed response but noted that he had been "putting his affairs in order in case the Pithotomy was of such magnitude that he became swallowed up or down, never to re-appear."

One faculty member commented on "your celebration and deification of the Hopkins medical faculty, who so richly deserve all you say about them." A former faculty member, now chairman of another prestigious department of medicine, wrote as follows:

I am sure the upcoming Pithotomy will maintain the highnot to say reeking — standard of past ones. Do not let deans or faculties or finances dissuade you. Lambast the living hell out of everybody; prick every balloon, and deflate every stuffed shirt! Irrigate the alley, shock the neighbors, and have a fine time.

Another respondent sent a letter typed in all caps with no spaces and no punctuation, in which he expressed his

abysmal disappointment at not being able to attend the cultural and educational gathering which has been reputed to be the ne plus ultra of all annual functions held by any organization in the city of Baltimore or the State of Maryland or the Federal Union of States, and furthermore, I am a stupid, ignorant, crude, unthinking jackass for having made a previous engagement which, alas, I cannot break. In short, God damm it, I cannot come.

He signed the letter "miserably" and then stated that if he didn't get an invitation next year, he would "personally set fire to your clubhouse and put arsenic in [faculty advisor] Alan Wood's coffee."

Women faculty, being barred from attending the show, were almost universally ignored. If one was mentioned at all, it was in the context of a favorable comparison with a bungling, incompetent, ignorant male faculty colleague. The club ignored this guiding principle to its detriment in 1982, when it portrayed a rising female faculty star, Bernadine Healy, in a most unfavorable way.

The show opened with the president, attired in academic gown and mortarboard, singing the traditional opening salvo, "Welcome, welcome, all you strangers." This was set to a tune called Ruben and Rachael, a campfire sing-a-long tune popular in the 1870s. The song went like this:

Welcome, welcome, all you strangers

Now's the time for this year's show.

Four long years you've ground our a ...

Now we let you bastards know.

In years gone by, don't ask me why

My predecessors have seen fit

As April wanes and May draws nigh

To ferret out each hypocrite

Occasionally, special guests were present who were duly acknowledged with their own special verse. One year the president of the university board of trustees, having heard that the antics of the club might be getting out of hand, showed up to see for himself. This distinguished banker and Yale graduate was greeted thusly:

And this evening we have with us

A Robber Baron and Trustee.

Charley Garland sits down here

So try to hit him when you pee.

Another year a distinguished Oxford surgeon, Mr. Phillip Allison, was visiting Dr. Blalock and accordingly received an invitation to the show. His RSVP was written on stationery 


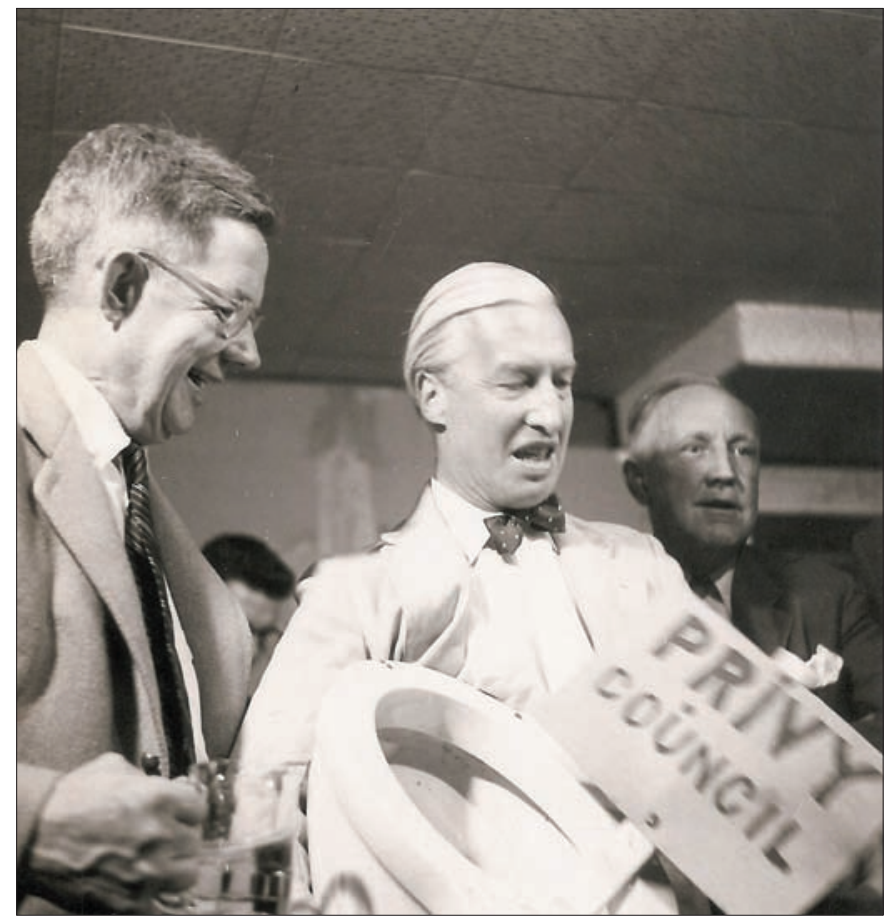

Figure 6. Professor Allison of Oxford finds his seat for a Pithotomy show. Also shown are Alfred Blalock and Dean Alan Chesney. Photo: W. Jarrett.

indicating that he was a member of the Queen's Privy Council. Upon learning that, some enterprising Pithotomists found an abandoned toilet bowl, cleaned it up, and created his seat for the performance (Figures 6 and 7). His presence was acknowledged with the following ditty:

This British surgeon here among us Has laughed along with main and might.

But, as we have always told you

You will not get off to-night.

You've publicized the diaphragm

And are a famous cuss.

But any friend of Al Blalock's

Is just a shit to us.

Instead of being offended, Mr. Allison thoroughly enjoyed the evening, and at the conclusion of the show he added several English and Scottish limericks to the club's already extensive repertoire. In his thank you note, he whimsically wrote,

I am returning one of the balls that was carried away, in the hope that it may be returned whence it was dislodged. The lavatory and the Grand piano that were removed at the same time have unfortunately been misplaced.

He included a check for $\$ 100$, was made an honorary member of the Pithotomy Club, and was given a tie, which he apparently wore on Wednesdays on his return to England.

\section{THE PITHOTOMY SONG: "3000 YEARS AG0"}

The show traditionally concluded with the singing of a multiversed song, called "3000 Years Ago." The tune is catchy and

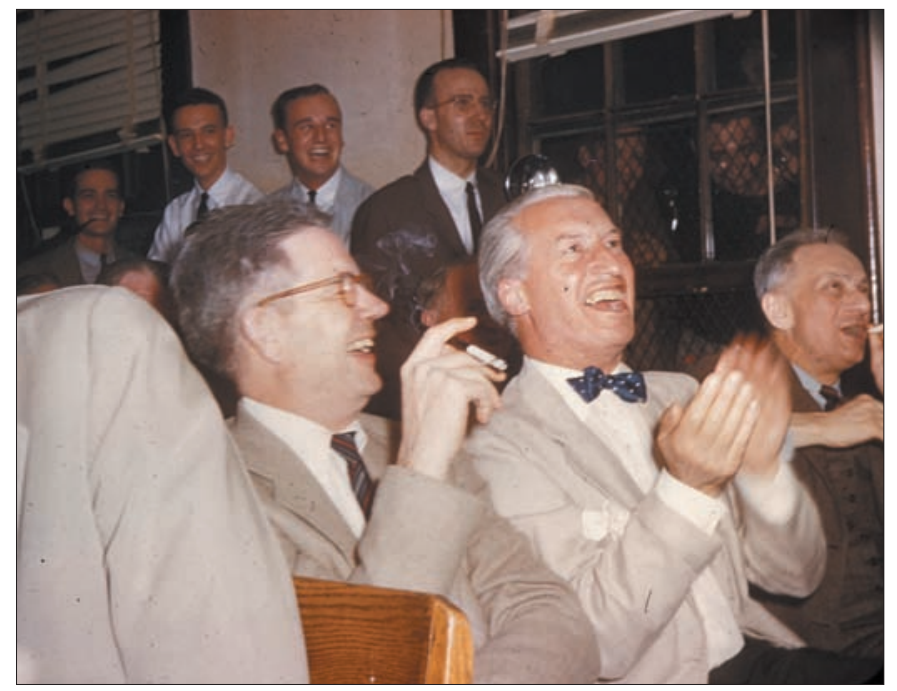

Figure 7. Professors Blalock and Allison enjoy the show! Photo: W. Jarrett.

infectious and is said to have originated in a Baltimore burlesque theater. It was introduced "into this world of sin and strife" in the 1925 Pithotomy show. Longtime attendees knew the words by heart and joined along in the singing. There are literally hundreds of verses, as each class added a half-dozen verses to the already existing trove.

The setting recreates the "Three Fates," a famous photo of Halsted, Osler, and Kelly (Figure 8). The Max Broedel cherub, usually the burliest senior student, was seated on an empty beer keg, swinging a caduceus in one hand and a mug of beer in the other, clad only in a towel.

Here are the opening verses of "3000 Years Ago":

This little song of woe-begone

Bespeaks a Parable.

Everyone will now admit

Comes from the depths of Hell

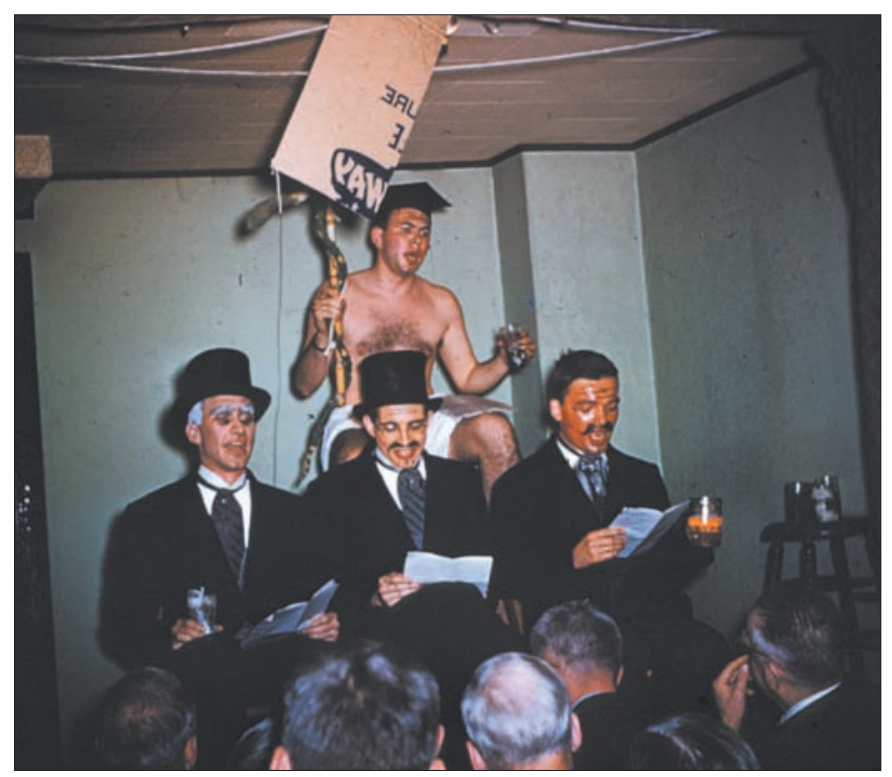

Figure 8. Singing of "3000 Years Ago," modeling "The Three Fates." Photo: W. Jarrett. 
3000 years ago

3000 years ago

We are the singers of the past

When Cleopatra reigned.

No one knows how many men

That wench did drive insane.

3000 years ago, etc.

There then ensues endless repetitions of the same, each new verse a parody on some eminent clinician, as F. Scott Fitzgerald had so accurately noted. Unfortunately, most of these verses are too scurrilous to be reprinted here. Here are a couple that pass the test of censorship:

In Public Health we waste our time

In learning the percent

Of three-hole privies in the state

Our time is not well spent.

3000 years ago, etc.

The indoor can is much the best;

The shit is flushed away.

But the shit that flows in that damn course

Would flood the USA.

Another verse describes the problems faced by many a patient in his first encounter with a teaching hospital:

Patients come to Hopkins

To get cured of many ills.

They hope to get some treatment

Or at least a few pink pills

3000 years ago, etc.

Instead they get a Wasserman

A chest plate and a Frei;

The motto is, get all the tests

Before you let them die.

The next is an example of a back-handed compliment to a female faculty member. The "singer" is Dr. Blalock, and the "Helen" referred to is Helen Taussig, the eminent pediatric cardiologist. It was common knowledge that Dr. Blalock and Dr. Taussig did not get along.

Now I'm not sure, but I believe

That this h're child is blue.

Oh, Helen, won't you help me,

cuz I don't know what to do.

The final example refers to the chairman of urology:
And in his lab there stands a jar

And 'tis his fondest hope.

To get at last the prostate of

His Holiness the Pope.

The song concludes with reference to "a little game of chance," a crap game, whose intention was to recoup some of the expenses of the show. The evening ends with more verses of "3000 Years Ago," limericks both old and new, and a song popular in the 1930s, "The Old Black Bull." These were enthusiastically rendered by the senior faculty, whose vulgarity rivaled or exceeded that of the medical students.

\section{THE DECLINE AND FALL OF THE PITHOTOMY CLUB}

Everyone I contacted about this paper agreed that a seminal event along the road to the club's eventual demise occurred in 1982, when the show unwisely targeted an uninvited female faculty member, Dr. Bernadine Healy, with a particularly harsh denouement. Dr. Healy at the time was a rising star in cardiology who went on to become the first female president of the American Heart Association, head of the National Institutes of Health, and later head of the American Red Cross. They picked on the wrong lady! She took extreme offense, appeared at the dean's office the next day with demands that the club be shut down and the students be severely reprimanded, and threatened a 7-figure lawsuit for defamation of character. The students responded by engaging the American Civil Liberties Union to defend their rights of free speech. Eventually, cooler heads prevailed and no lawsuit was filed, but hard feelings remained and Healy continued to rail against the club in a New England Journal of Medicine article and in a 1992 interview in The Washington Post, as well as in her biography. Such adverse publicity undoubtedly hurt the club; for several years the show was voluntarily suspended and many previously supportive faculty felt that the club had crossed the line of decency. And perhaps it had.

Contrast this with a more traditional treatment of female faculty members from a previous Pithotomy show, when they were parodying Bernadine Healy's then-husband, a Hopkins surgeon named Gregory Bulkley:

His wife has the brains

His wife has the looks

His wife is both charming and chic;

While he is a boor

He is a jerk

And everyone laughs when he speaks

Yes, she writes the papers

She wears the pants

While he wears his head up his rear.

There is no record of a complaint having been lodged after that particular show. 


\section{THE DEATH OF THE PITHOTOMY CLUB}

As time passed, changes appeared at Johns Hopkins. Female enrollment soared, cutting down on the applicant pool available for club membership. Eventually, in 1990, the club changed its longstanding policy and began to admit women. The medical school changed its scheduling, such that first-year students had the afternoon off, thus negating the need for an afternoon meal or for a place to provide such. Instead of living in the immediate neighborhood of the school, more and more of the students lived away, another factor that negated the need for the club.

The club was forced to sell its property at 731 North Broadway to make way for further medical school expansion, and the new facilities, around the corner on Madison Street, were smaller, cramped, rat-infested, and crime-ridden. The new club had no kitchen, and thus no meals were served. It functioned solely as a meeting place to bring together faculty and students for informal discussions and dialogue. Even though nonmembers were invited to these gatherings, the club was subjected to charges of elitism and exclusivity by other students. Until the club changed its rules and began to include women, some faculty seemed reluctant to accept invitations to speak to the members of an all-male group.

Crime was an ever-present concern. One break-in resulted in the theft of numerous signed photographs of prominent Hopkins faculty members that lined the walls of the club. Some of these were later recognized by a student in a downtown pawn shop and recovered, but some were lost, never to be seen again.

That scourge of our modern-day culture, political correctness, also played a major role in the demise of the Pithotomy Club. If ever there was an antithesis to political correctness, the Pithotomy Club would serve as exhibit A. But political correctness currently reigns supreme in our culture and is unbelievably destructive. Until women were admitted as members, the Pithotomy Club was viewed in some quarters as misogynist. Some female medical students, not to mention female faculty, regarded it as such, and the women exerted pressure on their male classmates not to associate with such lowlifes who dared to exclude women from their membership roster.
In any society, customs and values change over time. In recent decades, egalitarianism is "in" and any hint of privilege or elitism is "out." In this vein, both Harvard and Stanford abolished their Alpha Omega Alpha chapters, to me a foolish and irresponsible act but certainly in accordance with the changing mores. To the extent that the Pithotomy Club was elitist, its reputation suffered in this changing intellectual environment. Simply fewer and fewer medical students were attracted to the Pithotomy Club.

In 1992 the club closed its doors forever and donated its clubhouse to the medical school. Yet another research building occupies its former site. Thus ended a 95-year relationship with The Johns Hopkins Medical School, which had begun with the first graduating class. Lifelong friendships nurtured by Pithotomy Club membership remain and are cherished by many. It is hard for many of us to imagine the medical school without a Pithotomy Club to point out her foibles and failings.

Is Hopkins better off without the Pithotomy Club? I doubt it. There is something inherently healthy about having knowledgeable critics readily available to keep a faculty on its toes and keep them from believing their press clippings. Pride can be a dangerously destructive force, while humility is a virtue devoutly to be wished. I suspect that, some day, something will arise to fill the void left by the demise of the Pithotomy Club.

\section{SELECTED REFERENCES}

1. Harrell RA. The Pithotomy Club History. Unpublished manuscript, available at http://www.pithotomy.com/history.html.

2. Sergott RC, Olch PD. The Society of Pithotomists: 1897-1980. Paper given at the annual meeting of the American Osler Society, May 9, 1978, Kansas City, Missouri.

3. Worthington JF. The anals of Hopkins. Hopkins Medical News 2003(Fall):19-21.

4. Hayter CRR. Medicine's moment of misrule: the medical student show. J Med Humanities 2006;27(4):215-229.

5. Gladwell M. The Healy experiment. Washington Post Magazine, June 21, 1992.

6. Healy B. A New Prescription for Women's Health. New York: Penguin Books, 1995. 